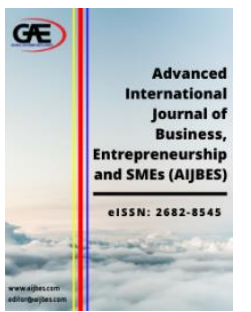

\author{
ADVANCED INTERNATIONAL JOURNAL OF \\ BUSINESS, ENTREPRENEURSHIP AND SMES \\ (AIJBES) \\ www.aijbes.com
}

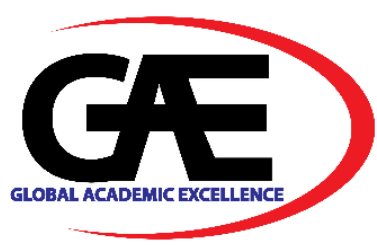

\title{
THE IMPACT OF CUSTOMER BUYING BEHAVIOR TOWARDS SMALL AND MEDIUM ENTERPRISES (SMEs) PERCEPTION DURING PANDEMIC (COVID-19) IN JOHOR
}

\author{
Mohamad Faiz Zainudin ${ }^{1}$, Sabrinah Adam ${ }^{2 *}$, Nursyazwani Mohd Fuzi ${ }^{3}$ \\ 1 Azman Hashim International Business School, Universiti Teknologi Malaysia (UTM), Malaysia \\ Email: faizutm96@gmail.com \\ 2 Azman Hashim International Business School, Universiti Teknologi Malaysia (UTM), Malaysia \\ Email: sabrinah@utm.my \\ 3 Azman Hashim International Business School, Universiti Teknologi Malaysia (UTM), Malaysia \\ Email: nursyazwani.mohdfuzi@utm.my \\ Corresponding Author
}

\section{Article Info: \\ Article history: \\ Received date: 08.07.2021 \\ Revised date: 15.07 .2021 \\ Accepted date: 20.07.2021 \\ Published date: 01.09.2021 \\ To cite this document: \\ Zainudin, M. F., Adam, S., \& Fuzi, N. M. (2021). The Impact of Customer Buying Behavior Towards Small and Medium Enterprises (SMEs) Perception During Pandemic (Covid-19) in Johor. Advanced International Journal of Business, Entrepreneurship and SMEs, 3 (9), 01-07.}

DOI: $10.35631 /$ AIJBES.39001.

This work is licensed under CC BY 4.0

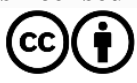

Abstract:

The objective of this study is to identify the conceptual framework of customer buying behavior and Small Medium Enterprises perception during Pandemic Covid-19 in Johor. The variables consist of Customer Buying Behavior (panic buying, herd mentality, role of the media in influencing consumer behavior) as an independent variable and Small and Medium Enterprises (SMEs) perception during Pandemic Covid-19 as the dependent variable. This study adopted a quantitative approach using IBM SPSS version 26. The survey was conducted on Johor SMEs firms. The conceptual framework has been developed in this study. The expected findings show there is a positive relationship between herd mentality, panic buying, and the role of the media have significant relationship toward SMEs enterprises during Pandemic Covid-19 in Johor.

Keywords:

Customer Buying Behavior, Small And Medium Enterprises, Covid-19, Johor 


\section{Introduction}

Pandemic Covid-19 outbreak was first reported in Wuhan, China, in December 2019. As of this writing, new science is published regularly as the resources of the world's health systems pour into learning about, treating and preventing human infections in more than 100 countries and on six continents. To bring this disease outbreak into context and discuss global health security and pandemic response preparation, we will first include some history of coronaviruses in this two-part article series (Mcleod, 2020). There are many coronaviruses known to circulate in different populations of animals which have not yet infected humans. COVID-19 is the latest to make a leap towards human infection (Mcleod, 2020).

Small and medium enterprises (SMEs) are enterprises that below a certain level retain their profits, assets or a number of employees. Every nation has its own idea of what constitutes a small and medium-sized business (SME). These size criteria must be met and the sector in which the organisation operates is often taken into account as well (Bartik et al., 2020). However, on a small scale, small and medium-sized enterprises (SMEs) play a significant role in the economy. They outnumber large corporations greatly, employ a large number of people and are typically entrepreneurial in nature, helping to shape innovation (Bartik et al., 2020).

SMEs play a key role in the Malaysian New Economic Policy. Since SMEs have been a significant generator of jobs and growth, they have long been recognised as the backbone of any economy. In Malaysia, for instance, SMEs account for about $99 \%$ of total business establishments and contribute to $38.3 \%$ of the Gross Domestic Product (GDP) of the country (Department of Statistics Malaysia, 2019). The GDP of Malaysia's SMEs surpassed Malaysia's GDP by 6.2 percent, which reached 4.7 percent in 2018. (Department of Statistics Malaysia, 2019). Johor is the country's third largest contributor to GDP, behind Selangor and Kuala Lumpur.

The coronavirus (Covid-19) has a far-reaching effect on companies, especially small and medium-sized enterprises. It's taken many lives already, and it's taking them, too. In addition, each country follows lockdown procedures as a means of preventing steps, and the same has been adopted by Malaysia as well. Both the private and the public sectors appear to be messed up because of this virus. It is inevitable that the effect of the new coronavirus will have a significant impact on the country, economy, and society. The rising risk of new coronavirus is a public health concern that hampers the entire macro economy. It has also cut off the firm's supply chain. Further hampering is required of the production and the manufacturers. China is the main production centre for many companies worldwide. Any disruption to Chinese output will therefore simply have repercussions (Hasanat et al., 2020).

During Pandemic Covid-19 in Malaysia, consumers have several concerns to bear, worrying about the safety of their self and families, whether they can pay for their basic needs, and losing the ability to fly. When clients change their old habits and adopt new ones, such growing issues manifest differently. It is clear that the MCO has had an influence on what people buy and how they buy it, but also on how much they spend while shopping (Kong, 2020). According to a special survey conducted by the Malaysian Department of Statistics on the effect of Covid-19 on the economy and individuals (Round 1) from 23 to 31 March 2020, there was a significant change in spending on daily needs before and after the outbreak of Covid-19. The buying pattern of raw materials on the market or in the warehouse or in the grocery store indicates that before the outbreak, the existing sales mostly and seldom changed according to Covid-19 (Kong, 2020). 
Volume 3 Issue 9 (September 2021) PP. 01-07 DOI 10.35631/AIJBES.39001

Covid-19 has affected companies, especially small and medium enterprises, to survive in the industry as they take various risks to keep their company going. Consumers should take the requisite precautions and be more likely to take proactive action based on the possible effects of this pandemic (Yannelis, 2020). Therefore, the consumer behaviour of Malaysia primarily impacts the e-commerce business market to a large extent. Consumer buying behaviour will be affected instead of national lockouts because there would be a lack of availability of goods and services in the various outlets and markets. To this end, the user will rely primarily on the online platform to fulfil the basic needs needed to survive (Craven, 2020).

Owing to confusion, people are postponing buying decisions in several categories. After the immediate menace has dissipated, this will continue. In China, for example, gold and silver sales fell in January and February 2020, year on year, by 41.1 percent. There will be a waitand-see attitude. It will affect several sectors, especially SMEs. Regardless of the strain caused by the COVID-19 pandemic, significant constraints are being forced on the SME. The dependent variable is known as the SME since the rise or decrease in demand for the particular platform is heavily dependent on the widespread COVID-19 and on the consumer's behaviour towards this global problem as well. The company is mainly reliant on these two factors that influence its overall market demand. For this reason, clients have switched to online network approaches. It is seen as the only way the population of the world can survive the pandemic situation. Increased viewer numbers are seeking to take advantage of digital facilities.

\section{Literature Review}

\section{Customer Buying Bahavior}

Customer buying behaviour is the study of consumers and the mechanisms they use to use, select, and dispose of goods and services, including mental, emotional and behavioural responses from consumers. In how Covid-19 influences SMEs, consumer behaviour integrates concepts from many disciplines, including psychology, genetics, chemistry, and economics (Hasanat et al., 2020). Customer buying behavior has led to the retention of customers in Johor SMEs. Recent research shows that the main purpose of consumer behavior is to help retain and create customers (Ding et al. 2020). A customer who is happy about a particular product or service repeatedly purchases the same product. Marketing of products is done in a way that customers can repeatedly make purchases of similar products (Muniyappa \& Gubbi, 2020). Thus, to track and retain more customers during the pandemic, more small and medium enterprises have paid attention to consumer behavior.

Customer buying behavior during the pandemic in Johor has led to the prediction of market trends. According to recent trends of consumers, more customers are attracted by healthy food and a friendly environment (Bayissenge et al. 2020). By considering customer's behaviors, more small and medium enterprises have saved a lot of resources by putting on hold commodities that are not in high demand during the pandemic to avoid losses and wastage. Basing on consumer behavior, small and medium enterprises have decided on a production strategy that is saving marketing and warehouse costs.

As a result of buyer behavior, customer service in Johor and its environments has been improved during the pandemic. In small \& medium enterprises, consumers need different customer services. Comprehending the differences in customer base has led to the production of the most appropriate customer service which has impacted positively in the sales and market. For instance, to help catch customer's attention over a certain product, say a newly innovated 
Volume 3 Issue 9 (September 2021) PP. 01-07 DOI 10.35631/AIJBES.39001

product, one has to employ more customer service to help the public understand the usage of similar products. In this case, as a result of buying behavior, new products were innovated in Johor (Shamsuddin et al. 2020). Many customers were employed to serve customer service and aid in understanding the usage of new products in the market. For instance, when the pandemic struck Johor, many people opted to buy televisions to keep following the updates during the lock down (Krishnan, 2020). As a result, marketers learned consumer's preferences and imported a lot of televisions as well as human support to help customers comprehensively understand how to use electronic gadgets.

\section{Dimension of Customer Buying Behavior}

\section{Panic Buying}

Yuen et al. (2020) conducted some research had identified 4 key factors that trigger panic purchases in response to the coronavirus fear of the unknown, awareness and social psychology coping behaviour. They concluded that when consumers consider the probability and effects of contracting a disease to be higher, they are motivated to conduct self-protective behaviours, including panic purchasing, to minimise perceived risk. In addition, if people demand a product to become unavailable and thus restrict their personal freedoms by not having it, panic buying would be encouraged; or alternatively, if they may expect a sense of guilt that they do not pursue a certain action or purchase, leading them to make these scheduled purchases (Yoon et al. 2017). Fear of the unfamiliar is expressed in panic buying behaviours as clients turn their lack of knowledge of emergencies into behaviours that are seen as calming, offering protection or relieving stress (Elmore 2017). This is expressed in research showing that, in anticipation of imminent disasters, SME sales have traditionally risen.

\section{Herd Mentality}

Herd mentality is defined as an alignment of the ideas and/or behaviours of individuals in a community that emerges without the purposeful planning of a central authority or leading figure, rather than through local interactions between agents (Kameda and Hastie, 2015). The impact of a knowledge cascade is shown by behavioural economics, whereby clients with a network are influenced by others' behaviours and choices (Easley and Kleinberg 2010). Furthermore,' shortage heuristics' often play a role in the growth of market anxiety during times of shock, so that usually boring products frequently see their value irrationally inflated by the demand (Cheung et al. 2015).

\section{Role of Media in Influencing Consumer Behavior}

In the digital world, mass media plays a key role in the growth, remodelling and leadership of public opinion (Yang et al. 2019). The research of the 2014-15 Ebola outbreak is the most recent and significant indicator for observing the effect of media coverage on consumer behaviour. Therefore, when the first death took place in the US, other behavioural anomalies mentioned earlier in the study, such as panic buying and herd mentality, were affected by scaremongering and panicked media coverage. Mass media positions across channels have grown. SMEs need to use media channels carefully during the Pandemic Covid-19 since only this channel is deemed acceptable as an approach to finding customers.

\section{Small Medium Enterprises Problem During Pandemic Covid-19}

Small and medium enterprises (SMEs) are enterprises that below a certain level retain their profits, assets or a number of employees. Every country has its own concept of what constitutes a small and medium sized enterprise (SME). Such size criteria must be met and the sector in 
Volume 3 Issue 9 (September 2021) PP. 01-07 DOI 10.35631/AIJBES.39001

which the company operates is also often taken into account (Bartik et al., 2020). Small Medium Enterprises (SMEs) is an independent company with a small market share and controlled by its owner or part-owners (Margaretha \& Supartika, 2016). SME are wide diversity of the businesses, so there is no single definition of a small firm because each country has their own definition for SME Firm.

Malaysia's economic is forecast to fall after the Pandemic Covid-19 with 93 per cent of small and medium enterprises (SMEs) expected to face problem business within six months. The government needs at least six months after the crisis in an effort to restore the country's economy (Raman, 2020). SMEs in Johor also affected due to Covid-19 and having a lot of problem such as deterioration in business performance; declining demand and product offerings; lack of stock of raw materials; limited product production; difficulty paying rent for business premises; and difficulty repaying business loans (Idris, 2020). There are many sectors affected by the Covid-19 outbreak including the manufacturing, tourism, education sectors and food industry (Zainuddin, 2020).

\section{Conceptual Framework}

The conceptual framework of this study has been developed as follows;

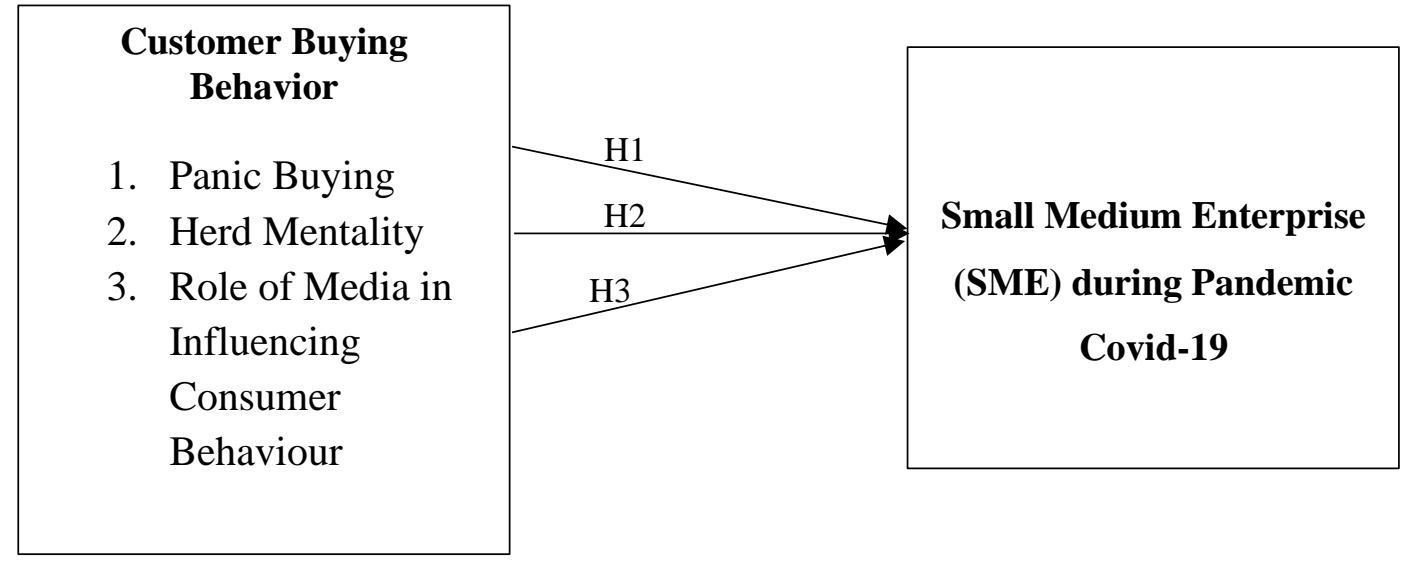

Figure 1: Conceptual Framework

\section{Methodology}

The population of this study consists of SMEs companies in Johor. The list of registered SME companies has been obtained from SmeCorp (2019) there is 68,874 SME has been refined and focused solely on the state of Johor. A quantitative approach using self-administered questionnaire was adopted. Stratified sampling technique was adopted to distribute questionnaire to SMEs companies in Johor. The data will be analysed using the Statistical Package for the Social Sciences (SPSS) version 26 to evaluate the impact of consumer buying behavior during Covid-19. Numerous data analysis sets will be used in this study such as analysis on reliability, descriptive analysis, t-test, one-way ANOVA, analysis of multicollinearity, and analysis of multiple regressions.

\section{Conclusions}

The conclusion, this study will benefit the small-medium enterprise (SME) to help them for better understanding in preparing strategies to support their company during the Covid-19 pandemic. This study also will help the SME to unlock their potential to further explore and 
Volume 3 Issue 9 (September 2021) PP. 01-07 DOI 10.35631/AIJBES.39001

construct effective strategies to reach the right customer, that eventually would boost their sales especially during pandemic.

\section{References}

Bartik, A. W., Bertrand, M., Cullen, Z. B., Glaeser, E. L., Luca, M., \& Stanton, C. T. (2020). How are small businesses adjusting to covid-19? early evidence from a survey (No. w26989). National Bureau of Economic Research.

Bayisenge, R., Shengde, H., Harimana, Y., Karega, J. B., Lukileni, M., Nasrullah, M., \& Nteziyaremye, B. E. (2020). Contribution of small and medium enterprises run by women in generating employment opportunities in Rwanda. International Journal of Business and Management, 15(3), 1833-8119.

Cohen, J. (1992). Statistical power analysis. Current directions in psychological science, 1(3), 98-101.

Department of Statistics Malaysia. (2019). Kuala Lumpur: Department of Statistics Malaysia Retrieved from https://www.dosm.gov.my/v1/index.php?r=column/cthemeByCat\&cat=159\&bul_id= R0Vka2RpeVJ0cUlpR3BqdjhudDZhdz09\&menu_id=TE5CRUZCblh4ZTZMODZIb mk2aWRRQT09.

Ding, W., Levine, R., Lin, C., \& Xie, W. (2020). Corporate immunity to the COVID-19 pandemic (No. w27055). National Bureau of Economic Research.

Hasanat, M. W., Hoque, A., Shikha, F. A., Anwar, M., Hamid, A. B. A., \& Tat, H. H. (2020). The Impact of Coronavirus (Covid-19) on E-Business in Malaysia. Asian Journal of Multidisciplinary Studies, 3(1), 85-90.

Kong, S. (2020). Covid-19 changes consumer buying behaviours. Borneo Post Online. Retrieved from https://www.theborneopost.com/2020/04/26/covid-19-changesconsumer-buying-behaviours/

Krishnan, H. (2020). The Relationship Between Organizational Justice Perception and Job Satisfaction in Small and Medium Enterprises. Journal of Arts \& Social Sciences, 4(1), 31-44.

Majid, T. A., Azman, M. N. A., Zakaria, S. A. S., Yahya, A. S., Zaini, S. S., Ahamad, M. S. S., \& Hanafi, M. H. (2011). Quantitative analysis on the level of IBS acceptance in the Malaysian construction industry. Journal of Engineering Science and Technology, 6(2), 179-190.

Margaretha, F., \& Supartika, N. (2016). Factors affecting profitability of small medium enterprises (SMEs) firm listed in Indonesia Stock Exchange. Journal of Economics, Business and Management, 4(2), 132-137.

Mcleod, V. (2020). COVID-19: A History of Coronavirus. Lab Health And Safety. Retrieved from https://www.labmanager.com/lab-health-and-safety/covid-19-a-history-ofcoronavirus-22021

Muniyappa, R., \& Gubbi, S. (2020). COVID-19 pandemic, coronaviruses, and diabetes mellitus. American Journal of Physiology-Endocrinology and Metabolism, 318(5), 736-741.

Raman, H. (2020). Langkah pemulihan PKS pasca pandemik COVID-19. Astro Awani. Retrieved from http://www.astroawani.com/berita-malaysia/langkah-pemulihan-pkspasca-pandemik-covid-19-240620

Shamsuddin, J. B., Minai, M. S. B., Zain, A. Y. B. M., \& Al Idrus, S. (2020). Relationship of perception and awareness towards the utilization of government business support services (GBSS) in Malaysian SMEs perspective. Journal of Entrepreneurship Education, 23(1), 67-76. 
Volume 3 Issue 9 (September 2021) PP. 01-07

DOI 10.35631/AIJBES.39001

Zainuddin, M. Z. (2020). COVID-19: Kerajaan analisis kesan ke atas sektor terjejas. Berita Harian.

https://www.bharian.com.my/berita/nasional/2020/06/695534/covid-19-kerajaananalisis-kesan-ke-atas-sektor-terjejas 